\title{
Selected Abstracts from International Business History Journals
}

\author{
Zeitschrift für Unternehmensgeschichte \\ [Journal of business history] \\ Vol. 61, No. 1 (2016):
}

Florian Triebel, "Set Up a Business and Talk about It: Business Foundation and Communication-the Example of BMW (1916 to 1923)." Communication matters. To secure a successful position in their markets, corporations have to advertise themselves, their brands, products, and services. Particularly during the founding of a firm, all aspects of communication are of great significance. The article examines the first stages in the history of Baye rische Motoren Werke (BMW), focusing on external communication efforts. Having initially been set up as supplier for the rising airplane industry during the Great War, BMW had to find new business models after the surrender of the Kaiserreich. During the founding and transformation processes, which finally turned BMW into a vehicle manufacturer in 1923, communication played an essential role in responding to the influences of the volatile external environment and reflecting the changing business strategies of BMW.

Florian Schneider, "The Medici Bank and Its Structure in the Context of Its Presence." This article examines the rise and fall of the medieval Medici Bank in order to shed light on the emergence of a "modern" banking sector in Europe. Special attention is paid to the bank's structure and organization, which is analyzed in the tradition of the work and ideas of Karl Polanyi as being embedded in the specific historical institutions of medieval Europe. The article shows that both the medieval banking sector and the structure and organization of the Medici Bank reflected the highly specific institutions and circumstances of their time. Furthermore, it investigates in detail how such an organization had to be shaped in order to overcome the economic difficulties of the fourteenth century. Finally, the article discusses the organization of the Medici Bank against the background of modern business organization theory. Based on Alfred D. Chandler's concepts, the Medici Bank can be identified as a very early multidivisional form of organization. 
Nicolai Hannig, "Machine Damage: Insurance and Prevention of Industrial Accidents around 1900." Accidents are constant companions of technology. At first glance, they do not seem to follow any rules; in fact they appear to be hardly foreseeable. This impression heightened when machines began working more and more autonomously while at the same time fewer people understood their operating modes. The search for preventive measures is and always has been affiliated with accidents, all the more so since the beginning of industrialization. Technology played a paradox role in these developments: It triggered prosperity and wealth on the one hand, but created new risks on the other. Furthermore, technology was both the main cause of accidents and the producer of modern methods of prevention. It was only a matter of time before insurance companies reacted to these new dangers by creating specific products. This article examines how insurance companies shaped ways of dealing with technological dangers, and it investigates the ways in which they managed to develop exceptional expertise, especially concerning machines. I argue that the insurance business gave a decisive impetus toward prevention of industrial accidents and mechanical breakdowns. During the advancing industrialization big companies, such as Allianz, Munich Re, and Swiss Re, became more and more professional in developing new techniques of prevention. They designed building regulations, set up requirements for preventive maintenance and cleaning, and carried out material testing. Particularly since the 1920 s they experimented with psychotechnologies that should prevent certain damaging events before they occur. Their results became part of a concerted media policy. Later, in the interwar period, big insurance companies started to publish specialized journals in which they presented some of their own new approaches toward preventive measures. In this way, self-promotion and prevention merged almost unrecognizably.

$$
\text { Vol. 61, No. } 2 \text { (2016): }
$$

Kerstin Hoffmann, "Playing Managers: Management Games in West German Companies during the 1960 s and 70s." In the 1950s, management games emerged and were established as an attractive training method for economic executives in the United States. In the following decades, this new method reached the German-speaking countries. How business simulation games found their way into management training at German companies has not been scientifically examined so far. Therefore this article tries to give a comprehensive overview of the early history of management games in West Germany and shows which companies used which business simulation games. The question 
of if and how management games are associated with organizational changes in large German enterprises in the 1960 s is of particular interest. The article provides a brief overview of the context in which management games emerged and examines how they were transferred from the United States to West German companies. There are mainly two ways that transfer can be identified. While companies like Hoechst, Bosch, Siemens, Kaufhof, or the Dresdner Bank developed their own gamesbased on their specialized business needs-others simply bought universal games from external providers or sent their executives to so-called management schools which used these kinds of games in their training. The essay also takes a look at the role and impact of management games in German companies. It shows that business simulation games were developed specifically to introduce executives to new tasks and structural changes that arose in the context of organizational changes in the 1960 .

Simon Tywuschik, "A Comparative Analysis of Corporate Environmental Protection within the German Chemical and Automobile Industries between 1960 and 2005." This paper looks into the evolution of corporate environmentalism in two German industries over a period of more than forty years. The theoretical framework of this longitudinal comparison is drawn from the findings of the New Institutional Economics. The evidence from the quantitative and qualitative archival data analysis indicates that corporate environmentalism passed a historic peak at the beginning of the 1990 s in the German chemical industry while being a time-invariant niche in the automotive industry. The article identifies coercive regulatory forces as the core element in the explanation for the evolution of corporate environmentalism. Moreover, the data show that societal pressure seems to be sector specific rather than a linear function over time. The article contributes to the literature on social and environmental responsibility by deepening the understanding of the ups and downs of corporate attention to environmental issues.

\author{
$* * *$ \\ Entreprises et histoire \\ [Companies and history] \\ Vol. 81 (2015):
}

Hicham Benaissa, "Islam et capitalism: Les entrepreneurs musulmans en France" [Islam and capitalism: Muslim entrepreneurs in France]. Although "Muslim" entrepreneurship in France is a significant phenomenon, it has not yet been the subject of significant research. This article 
addresses the topic with the results of a quantitative and qualitative survey of Muslim entrepreneurs in France. The author analyzes how such entrepreneurs adjust their practices to reconcile two areas of their lives. One is the area of their religious beliefs and practices that are the result of their individual and collective histories that have mainly been transmitted within the family sphere. The other area is that of the structures and the objectives of the business. The article highlights how the entrepreneurial logic focusing on profitability and performance can call into question the relationship to beliefs and religious practices and how this can lead to adaptations up to a certain degree and with certain threshold effects.

Isabelle Jonveaux, "Des moines entrepreneurs: Coûts et avantages de la structure religieuse pour l'activité économique" [Entrepreneurial monks: Costs and benefits of being a religious organization when running a business]. Monks are known in France for producing gastronomical products such as wine, cheese, and beer, which are part of the national heritage. The primary goal of monastic life is not to develop businesses, however, as monks are destined to consecrate themselves totally to God. This article considers how monks managed to combine economic activities and contemplative life without spoiling the latter. One of the consequences of their requirement to live independently from society is that such communities have to find a way to provide for themselves. Through fieldwork conducted in principally Benedictine monasteries in five European countries, the author outlines how monks try to build an alternative economy that remains true to their monastic values.

\section{Vol. 82 (2016):}

Ove Granstrand, "Histoire du management de la prise de brevets et de la propriete industrielle: Le cas Japonais" [The history of patenting and IP management: The case of Japan]. This article examines what is termed a "patent culture" in large Japanese companies. While these companies initially developed patent management capabilities under U.S. leadership in order to catch up with Western firms, they have gradually developed specific intellectual property management practices that are now of interest to non-Japanese firms. The article studies the historical conditions for the emergence of this "patent culture" and highlights its main features, particularly in terms of organizational choices and resource allocation.

Patricio Sáiz, "Les brevets comme outils de gestion: Les strategies d'affaires et d’innovation de Babcock et Wilcox en Espagne” [Patents 
as corporate tools: Babcock \& Wilcox's business and innovation strategies in Spain]. Babcock \& Wilcox, a U.S. company specializing in industrial boiler construction, was established in Spain in 1916 and is now considered one of the first great modern multinational companies. This article views the history of its long evolution through the prism of patent policies. Based on numerous documents, it provides an indepth analysis of industrial property strategies implemented by the company throughout the twentieth century.

\section{Vol. 83 (2016):}

Lee D. Parker, "Le Fayol de la mondialisation: Management contemporain et traces comptables" [The global Fayol: Contemporary management and accounting practices]. Henri Fayol traditionally has been regarded as a leading French industrialist of his day who pioneered development of early management theory in the classical management school tradition. However the influence of his ideas has spread far beyond his shores and the school of thought with which he has been identified. This study reflects upon his complex professional profile, his interdisciplinary disposition, and his unique and lasting contributions to contemporary management theory and accounting practices. These are reviewed with respect to the diversity of theoretical perspectives for which his ideas were arguably prescient. His unique orientation and contributions are also traced to their emergence in various contemporary aspects of accounting, management control, budgeting, and financial management. The international durability and pervasiveness of his theories are reflected in parallels between the industrial and market environment of his day and the global environment within which management and accounting is conducted today.

Armand Hatchuel, "Henri Fayol et la theorie du chef d'entreprise: Une nouvelle figure de l'autorite au tournant du $\mathrm{XX}^{\mathrm{e}}$ siècle" [Henri Fayol and business manager theory: A new figure of authority at the beginning of the twentieth century]. Before he wrote his famous tract, Henri Fayol was a chief executive officer (CEO), an innovator, and a scientist who considered scientific research to be a major responsibility for the head of company. However, as science became the driving force of a new industrial world, it also created an unprecedented connection to the future as it required the "unknown" be taken into consideration. This analysis encourages us to re-read Fayol as he wanted to be read. Far from being universal and common, his administrative doctrine is made up of original ideas and concepts (prévoyance-foresight, inconnu-unknown, programme 
d'action-program of action, perfectionnement-improvement, and constitution du corps social-constitution of the social body) whose theoretical and political impact has been underestimated.

As a result, Fayol was able to imagine a new type of business leader without relying on corporate language nor on the political economy of his time. His outline of a "political/ creative" model for a business manager's action draws from the heritage of the Enlightenment and from political and social philosophy. While this message should have marked a major turning point, Fayol's originality was subsequently diluted. A century later, it still offers valuable theoretical resources to propose alternatives to a financialized concept of firms.

\section{$* * *$ \\ Red de Estudios de Historia de Empresas \\ [Business history studies network bulletin]}

The business history studies network (REDHE, by its acronym in Spanish) is issued every semester in Spanish. Its purpose is to provide virtual information and become a discussion forum for researchers from several fields who are interested in business history.

\section{No. 22 (Aug. 2016)}

The bulletin presents a review of some publications and events in the business history discipline on Latin America. In the debates section, Diego Szlechter, Florencia Luci, and Marcela Zangaro introduce a revision to the sociological approaches to management in Argentina. The authors emphasize the need to study the evolution of local management since the 1960 s when the first managerial practices arrived in the country. They claim that the discussion in the literature has been more focused on the role of entrepreneurs in development and less on the impact of founders and managers within the company. Although, professional managers were only introduced later in large domestic companies, the authors call attention to the challenging environment in which to introduce new perspectives on the study of local management.

Also in this issue, Gabriela Recio comments on a book about business, businessmen, and the political environment in Mexico coordinated by Marco Palacios (2015). There are also comments on the special issue on international business in Southern Europe in the Journal of Evolutionary Studies in Business, the new book by Marcelo Rougier on the 
Argentinian industrialization, and the one by María Lenis on Argentinean sugar entrepreneurs. The "Doctoral and Masters Theses" section presents the summaries of two theses: one submitted by Pablo Federico Pryluka (MSc in history, Universidad Torcuato Di Tella, "Reforma structural, expectativas y consumidores: el problema de la inflación en la política económica de Martínez de Hoz"); and the other by Agustina Vence Conti (PhD in history, Universidad Torcuato Di Tella, "Resolver el problema de la deuda externa. Bancos, agentes financieros y gobierno en las negociaciones sobre la deuda pública Argentina después de la crisis de 1890: la trama de las negociaciones [1890-1907]").

In the section on resources, there is an invitation to join the new special interest group on food, agriculture, and sustainability; to join the group on globalization, growth, and inequality (Glocred); and to browse the Colegio de Mexico website on banking history in Latin America and Spain. The section on business history archives features the archives of two wine companies: Bodegas Arizu and Empresa Estatal Bodegas y Viñedos Giol.

\section{No. 23 (Dec. 2016)}

In this bulletin published by the end of 2016, the section "Debates" discusses the firm before industrialization. It includes an essay by Andrea Caracausi and reference to a work by Paolo Malanima published in Annali di Stori dell'Impresa (no. 14, 2003). Through a review of the literature, Caracausi discusses the nature of the pre-industrial firm, the types, and its internal organization. The author explores the characteristics of the pre-industrial firm, comparing them with the post-Chandlerian firm. The essay also includes a revision of the role of institutions in solving conflicts between and within firms, and their effect on the evolution of the market. Caracausi concludes that the study of the complexity of the pre-industrial firm needs to include other aspects such as family, religion, and culture. The pre-industrial firms must be seen as a reference to the characteristics of the so-called modern firm.

In this issue, two books are reviewed. Silvia Simonassi comments on a work about the relationship between Buenos Aires's port unions, the shipping companies, and the government in the early twentieth century (Caruso, 2016). Jorge Gilbert presents a study on family firms in the sugar industry in Tucuman between 1895-1930 (Moyano, 2015). Also, there are comments on the special issue on business groups published in Business History and a recent compilation on Latin American industrialization. "Doctoral and Masters Theses" presents a master thesis submitted by Maria Teresa di Salvo (MSc in Political Economy, FLACSO, "El 
impacto de la cultura organizacional en la sostenibilidad de las empresas recuperadas por sus trabajadores en la Argentina. Reflexiones en torno al caso Chilavert Artes Graficas").

"Resources" calls attention to the recent issue on food and agriculture published by the Business History Review (vol. 90, no. 3). The section on business history archives presents an essay by Laura Caruso on the sources for shipping companies available in Centro de Capitanes de Ultramar. 